\title{
MEMOTIVASI SISWA DAN SISWI SMK LETRIS INDONESIA DI DALAM MENENTUKAN PILIHAN UNTUK MELANJUTKAN PENDIDIKAN ATAU BEKERJA SETELAH LULUS SEKOLAH
}

\author{
Veta Lidya Delimah Pasaribu*, Fahmi Susanti, Elizabeth Tika Kristina Hartuti \\ Dosen Fakultas Ekonomi Universitas Pamulang \\ Email*: Vethalidya@yahoo.com
}

\begin{abstract}
ABSTRAK
Pengabdian ini berjudul Memotivasi Siswa dan Siswi SMK (Sekolah Menengah Kejurusan ) Letris II Indonesia Dalam Menentukan Pilihan Untuk Melanjutkan Pendidikan Atau Bekerja Setelah Lulus Sekolah. Tujuan pengabdian ini adalah untuk membantu memilih peluang tujuan, memberikan cara yang baik menetukan tujuan, membuka parakdigma siswa dan siswi terhadap keefektifan berkreativitas, memberikan semangat dan motivasi bagi para siswa dalam menjalani kehidupan. Metode yang digunakan adalah dalam bentuk penyampaian materi enterpreneur dan bidang pendidikan.Respondennya adalah para siswa dan siswi SMK (Sekolah Menengah Kejurusan )Letris II Indonesia Kesimpulan dari pengabdian ini adalah Peserta kurang mengerti apa yang harus dilakukan setelah lulus sekolah SMA nanti haru kuliah atau harus berkerja dan bagaimana cara memilih mana yang harus diproritaskan. Peserta juga belum mengetahui bagaimana memilih peluang dan apa yang harus dipilih nanti setelah lulus sekolah.Peserta juga belum mengetahui bagaimana memilih menjadi enterpreneur atau pendidikan apa yang dituju nanti.
\end{abstract}

\section{Kata Kunci: Enterpreneur, Pendidikan}

\section{PENDAHULUAN}

Seiring dengan perkembangan zaman tuntutan terhadap anak untuk melakukan berbagai macam aktivitas semakin meningkat. Tak terkecuali siswasiswi juga megalami hal yang sama. Bukan hanya aktivitas yang meningkat persainagn hidup setelah mereka bernajak dewasa. Oleh karena itu, mereka perlu dibekali dengan berbagai macam problem solving untuk menghadapi tantangan masa depan. Salah satu problem solving oleh pengabdian masyarakat kali ini adalah tentang bagaimana cara menentukan pilihan setelah lulus sekolah untuk lanjut pendidikan atau bekerja nanti. 
Para siswa dilingkungan kita, sebagian besar masih ragu dalam memilih tujuan mereka setelah lulus sekolah. Untuk itu sudah menjadi tugas kita agar mereka memiliki kepercayaan diri dalam menentukan arah hidup mereka.

Dengan adanya materi ini bagaimana cara menentukan pilihan setelah lulus sekolah, lanjut pendidikan atau bekerja , Para pemikiran siswa menjadi terbuka dan mampu mengatur arah hidup mereka secara mandiri dan bermanfaat untuk orang laindan bermanfaat untuk orang lain. Tampa melepas masa kanak-kanak mereka, segala keterampilan yang merka terima tetap dapat terlaksana. Perlu adanya dukungan dan pihak Yayasan untuk menjalankan pelatihan ini agar tersampaikan dengan maksimal

Menurut Prijosaksono dan Bawono (2005),entrepreneurship (wirausaha) dapat diartikan melalui 3 kata berikut: destiny, courage, action . Ketiga kata tersebut merupakan kata-kata yang penting dalam membangun sikap dan perilaku wirausaha dalam diri seseorang. Destiny berarti takdir, yang sebenarnya lebih merupakan tujuan hidup kita, bukan nasib. Tujuan dan misi hidup kita adalah fondasi awal untuk menjadi seorang wirausahawan yang sukses. Dengan memiliki tujuan hidup (life purpose) yang jelas, kita dapat memiliki semangat (spirit) dan sikap mental (attitude) yang diperlukan dalam membangun sebuah usaha yang dapat memberi nilai tambah dalam kehidupan kita. Keberanian (courage) untuk memulai dan menghadapi tantangan adalah sikap awal yang kita perlukan. Dalam kewirausahaan, keberanian untuk mulai dan mengambil resiko adalah syarat mutlak. Impian dan cita-cita yang besar, kemudian ditambah dengan kreativitas yang diwujudkan dengan keberanian untuk mencoba dan melakukan (Action) langkah pertama adalah awal kesuksesan seorang wiraswatawan sejati.

Pemimpin (leadership) adalah seorang pribadi yang memiliki kecakapan dan kelebihan - khususnya kecakapan-kelebihan di satu bidang, sehingga dia mampu mempengaruhi orang lain untuk bersama-sama melakukan aktivitasaktivitas tertentu untuk pencapaian satu beberapa tujuan. (Kartini Kartono, 2008 : 181).

\section{RUMUSAN MASALAH}

Dengan mempertimbangkan latar belakang yang telah diutarakan diatas kami berinisiatif untuk membentuk pengabdian masyarakan bagi siswa dan siswi kelas 3 melalui progam penyuluhan materi bagaimana cara menentukan pilihan setelah lulus sekolah, lanjut pendidikan atau bekerja bagi siswa dan siswi SMK (Sekolah Menengah Kejurussan) Letris II.Jl siliwangi No.47.Pamulang.Tangerang Selatan 
Membekali anak-anak para siswa dan siswi dengan bagaimana cara menentukan pilihan setelah lulus sekolah,untuk lanjut pendidikan atau bekerja.

\section{TUJUAN PELAKSANAAN}

1. Membantu memberikan arahan terhadap siswa dan siswi SMK Letris II dalam memilih tujuannya setelah lulus sekolah

2. Membuka paradigma siswa dan siswi SMK Letris II terhadap masa depan yang cerah.

3. Memberikan semangat dan motivasi bagi siswa dan siswi SMK Letris II dalam menjalani kehidupan setelah lulus sekolah

\section{TINJAUAN PUSTAKA}

\section{Pengertian Manajemen}

Pengertian manajemen secara umum dapat disimpulkan dari beberapa definisi menurut para ahli. Hal ini karena ada banyak versi definisi manajemen. Misalnya saja manajemen menurut seorang ahli bernama Mary Parker Follet yang mendefinisikan manajemen sebagai seni merampungkan pekerjaan melalui orang lain. Dari definisi tersebut didapati bahwa seseorang yang bertugas sebagai manajer dapat mengarahkan dan mengatur orang lain guna mencapai tujuan organisasi.

Di sisi lain, James A.F Stoner mendefinisikan manajemen sebagai proses pengorganisasian, perencanaan, dan penggunaan SDM supaya mencapai tujuan organisasi yang sudah ditetapkan.

Secara umum, pengertian manajemen merupakan suatu seni dalam ilmu dan pengorganisasian seperti menyusun perencanaan, membangun organisasi dan pengorganisasiannya, pergerakan, serta pengendalian atau pengawasan. Bisa juga diartikan bahwa manajemen merupakan suatu ilmu pengetahuan yang sistematis agar dapat memahami mengapa dan bagaimana manusia saling bekerja sama agar dapat menghasilkan sesuatu yang bermanfaat bagi orang lain maupun golongan tertentu dan masyarakat luas.

Secara etimologis, pengertian manajemen merupakan seni untuk melaksanakan dan mengatur. Manajemen ini juga dilihat sebagai ilmu yang mengajarkan proses mendapatkan tujuan dalam organisasi, sebagai usaha bersama dengan beberapa orang dalam organisasi tersebut. Sehingga, ada orang yang merumuskan dan melaksanakan tindakan manajemen yang disebut dengan manajer. 


\section{FUNGSI MANAJEMEN}

Pada dasarnya, fungsi manajemen dibagi menjadi tiga, yaitu:

\section{Perencanaan (planning)}

Pernecanaan adalah memikirkan apa yang akan dikerjakan dengan sumber yang dimiliki. Perencanaan dilakukan untuk menentukan tujuan perusahaan secara keseluruhan dan cara terbaik untuk memenuhi tujuan itu. Manajer mengevaluasi berbagai rencana alternatif sebelum mengambil tindakan dan kemudian melihat apakah rencana yang dipilih cocok dan dapat digunakan untuk memenuhi tujuan perusahaan. Perencanaan merupakan proses terpenting dari semua fungsi manajemen karena tanpa perencanaan, fungsi-fungsi lainnya tak dapat berjalan.

2. Pengorganisasian (organizing)

Pengorganisasian dilakukan dengan tujuan membagi suatu kegiatan besar menjadi kegiatan-kegiatan yang lebih kecil. Pengorganisasian mempermudah manajer dalam melakukan pengawasan dan menentukan orang yang dibutuhkan untuk melaksanakan tugas-tugas yang telah dibagi-bagi tersebut. Pengorganisasian dapat dilakukan dengan cara menentukan tugas apa yang harus dikerjakan, siapa yang harus mengerjakannya, bagaimana tugas-tugas tersebut dikelompokkan, siapa yang bertanggung jawab atas tugas tersebut, dan pada tingkatan mana keputusan harus diambil.

3. Pengarahan (directing)

Pengarahan adalah suatu tindakan untuk mengusahakan agar semua anggota kelompok berusaha agar dapat mencapai sasaran sesuai dengan perencanaan manajerial dan usaha.

\section{UNSUR-UNSUR MANAJEMEN}

Setiap perusahaan memiliki unsur-unsur untuk membentuk sistem manajerial yang baik. Unsur-unsur inilah yang disebut unsur manajemen. Jika salah satu diantaranya tidak sempurna atau tidak ada, maka akan berimbas dengan berkurangnya upaya untuk mencapai tujuan organisasi atau perusahaan. Unsurunsur tersebut diantaranya sebagai berikut.

\section{Human (Manusia)}

Dalam manajemen, faktor manusia adalah yang paling menentukan. Manusia yang membuat tujuan dan manusia pula yang melakukan proses untuk mencapai tujuan. Tanpa adanya manusia maka tidak ada proses kerja, sebab pada dasarnya manusia adalah makhluk kerja.

Money (Uang)

Uang merupakan salah satu unsur yang tidak dapat diabaikan. Uang merupakan alat tukar dan alat pengukur nilai. Besar-kecilnya hasil kegiatan dapat 
diukur dari jumlah uang yang beredar dalam perusahaan. Oleh karena itu uang merupakan alat (tools) yang penting untuk mencapai tujuan karena segala sesuatu harus diperhitungkan secara rasional. Hal ini akan berhubungan dengan berapa uang yang harus disediakan untuk membiayai gaji tenaga kerja, alat-alat yang dibutuhkan dan harus dibeli serta berapa hasil yang akan dicapai dari suatu organisasi.

Materials (Bahan)

Material terdiri dari bahan setengah jadi (raw material) dan bahan jadi. Dalam dunia usaha untuk mencapai hasil yang lebih baik, selain manusia yang ahli dalam bidangnya juga harus dapat menggunakan bahan/materi-materi sebagai salah satu sarana. Sebab materi dan manusia tidak dapat dipisahkan, tanpa materi tidak akan tercapai hasil yang dikehendaki.

Machines (Mesin)

Dalam kegiatan perusahaan, mesin sangat diperlukan. Penggunaan mesin akan membawa kemudahan atau menghasilkan keuntungan yang lebih besar serta menciptakan efisiensi kerja.

Methods (Metode)

Dalam pelaksanaan kerja diperlukan metode-metode kerja. Suatu tata cara kerja yang baik akan memperlancar jalannya pekerjaan. Sebuah metode dapat dinyatakan sebagai penetapan cara pelaksanaan kerja dengan memberikan berbagai pertimbangan-pertimbangan dari sasaran, fasilitas-fasilitas yang tersedia dan penggunaan waktu, serta uang dan kegiatan usaha. Perlu diingat meskipun metode baik, sedangkan orang yang melaksanakannya tidak mengerti atau tidak mempunyai pengalaman maka hasilnya tidak akan memuaskan. Dengan demikian, peranan utama dalam manajemen tetap manusia itu sendiri.

Market (Pasar)

Memasarkan produk tentu sangat penting sebab bila barang yang diproduksi tidak laku, maka proses produksi barang akan berhenti. Artinya, proses kerja tidak akan berlangsung. Oleh sebab itu, penguasaan pasar dalam arti menyebarkan hasil produksi merupakan faktor yang menentukan dalam perusahaan. Agar pasar dapat dikuasai maka kualitas dan harga barang harus sesuai dengan selera konsumen dan daya beli (kemampuan) konsumen.

Unsur- unsur manajemen menjadi hal mutlak dalam manajemen karena sebagai penentu arah perusahaan dalam melakukan kegiatan perusahaan. Selain itu, laporan keuangan juga menjadi penunjang dalam melaksanakan proses manajemen. Kini, Anda dapat membuat laporan keuangan dengan mudah menggunakan software akuntansi seperti Jurnal. Dengan menggunakan laporan keuangan dari 
Jurnal, Anda dapat lebih mudah melakukan kegiatan manajemen prusahaan hingga memudahkan dalam menentukan keputusan manajemen

\section{Pengertian Manajemen Sumber Daya Manusia}

Manajemen adalah ilmu dan seni yang megatur proses pemanfaatan sumber daya manusia dan sumber-sumber daya lainya secara efektif dan efesien untuk mencapai suatu tujuan tertentu.

Manajemen sumber daya manusia merupakan bagian dari ilmu manajemen yang memfokuskan perhatianya pada pengaturan peranan sumber daya manusia dalam kegiatan organisasi. Hal ini dikarnakan dalam mencapai tujuanya, organisasi memerlukan sumber daya manusia sebagai pengeelola sistemnya, dan agar sistem ini berjalan, dalam pengelolaanya diperlukan beberapa aspek penting, seprti pelatihan, pengembangan, motivasi dan aspek-aspek lainya. Hal ini yang menjadikan manajeman sumber daya manusia sebagai salah satu indikator penting pencapaian tujuan organisasi secara efektif dan efisien.( mila badriah, S.E.,M.M, 15: 2015).

Manusia selalu berperan aktif dan dominan dalam kegiatan organisasi karena manusia menjadi perencana, pelaku, dan penentu terwujudanya tujuan organisasi. Tujuan tidak mungkin terwujud tanpa peran aktif tanpa peran karyawan meskipun alat-alat yang dimiliki oleh perusahaan begitu canggih. Alat-alat canggih perusahaan tidak ada manfaatnya bagi perusahaan, jika peran aktif karyawan tidak di ikut sertakan. Mengatur karyawan merupakan hal yang sulit dan kompleks karena mereka mempunyai pikiran, perasaan, status, keinginan, dan latar belakang yang heterogen yang dibawa kedalam suatu organisasi. Karyawan tidak dapat di atur dan dikuasai sepenuhnya seperti mengatur mesin, moda, dan gedung.

Manajemen sumber daya manusia merupakan bagian dari manajemen. Oleh karna itu, teori-teori manajemen umum manjadi dasar pembahasaannya mengenai pengaturan peranaan manusia dalam menentukan tujuan yang optimal.

Pengaturan itu meliputi masalah perencanaan (human resources planning), pengorganisasian, pengarahaan,kompenasasi,pengintregrasian,pemeliharaan,kedisi plinan dan pemberhentian tenaga kerja untuk membantu terwujudnya tujuan perusahaan, karyawan, dan masyarakat.

Pengertian manajeman sumber daya manusia menurut malyu S.P. hasibuan ( 2005: 10 ) yang menyatakan bahwa :

"manajeman sumber daya manusia adalah ilmu dan seni yang mengatur hubungan dan peranan tenaga kerja yang efektif dan efisien membantu terwujudnya tujuan perusahaan, karyawan, dan masyarakat". 


\section{Motivasi}

Peran manusia yang tersedia di dalam perusahaan merupakan faktor utama untuk mencapai suatu tujuan perusahaan. Untuk menghendaki manusia agar sesuai dengan yang dikehendaki organisasi, maka harus dipahami motivasi manusia yang bekerja dalam organisasi tersebut, karena motivasi inilah yang menentukan perilaku orang-orang untuk bekerja.

Menurut Mangkunegara (2011:93) Motivasi adalah kondisi yang menggerakan pegawai agar mampu mencapai tujuan dan motifnya, sedangkan menurut Hadari Nawawi (2008: 351) motivasi adalah suatu kondisi yang mendorong atau menjadi sebab seseorang menjadi melakukan suatu perbuatan/kegiatan yang berlangsung secara sadar.

Menurut Hasibuan (2011: 143) mengatakan bahwa motivasi adalah pemberian daya penggerak yang menciptakan kegairaan kerja seseorang, agar mereka mau bekerja sama, bekerja efektif dan terintegrasi dengan segala daya upaya untuk mencapai kepuasan.

Robbin dalam Edy Sutrisno (2009: 117) menyatakan motivasi ialah "suatu kerelaan berusahaseoptimal mungkin dalam pencapaian tujuan organisasi yang dipengaruhi oleh kemampuan usaha memuaskan beberapakebutuhan individu". Sedangkan menurut M.Manulang dalam (2008: 194) yaitu motivasi merupakan pekerjaan yang dilakukan oleh seorang manajer memberikan inspirasi, semangat dan dorongan kepada orang lain, dalam hal ini karyawan untuk mengambil tindakan-tindakan. Pemberian dorongan ini bertujuan untuk menggiatkan orangorang karyawan agar mereka bersemangat dan dapat mencapai hasil sebagaimana dikehendaki dari orang-orang tersebut.

Berdasarkan uraian tersebut, diperoleh kesimpulan bahwa motivasi merupakan unsur penggerak yang mendasari seseorang dalam melaksanakan pekerjaan. Produktivitas kerja karyawan didasari oleh bagaimana motivasi yang dimiliki karyawan tersebut untuk bekerja. Jika karyawan termotivasi untuk bekerja dengan baik, maka produktivitas kerja karyawan juga akan menjadi baik dan cenderung untuk meningkat.

\section{Pengambilan Keputusan}

Menurut Ralp C. Davis menyatakan bahwa Keputusan ialah suatu hasil pemecahan masalah yang dihadapinya dengan tegas. Suatu keputusan adalah suatu jawaban yang pasti terhadap suatu pertanyaan. Keputusan harus menjawab sebuah pertanyaan tentang apa yang dibicarakan dalam hubungannya dengan suatu perencanaan. Keputusan bisa pula berupa suatu tindakan terhadap pelaksanaan yang sangat menyimpang dari rencana semula. 
Menurut Mary Follet menyatakan bahwa Keputusan ialah suatu hukum atau sebagai hukum situasiJika semua fakta dari situasi itu bisa diperolehnya dan semua yang terlibat, baik pengawas ataupun pelaksana mau mentaati hukumnya atau ketentuannya, maka tidak sama dengan mentaati suatu perintah. Wewenang tinggal dijalankan, tetapi itu adalah wewenang dari hukum situasi.

Menurut James A.F. Stoner menyatakan bahwa Keputusan ialah suatu pemilihan diantara alternatif-alternatif. Dalam definisi ini mengandung tiga pengertian, yakni :

- Ada pilihan yang berdasarkan logika atau pertimbangan

- Ada beberapa sebuah alternatif yang harus dan dipilih salah satu yang terbaik

- Ada tujuan yang ingin dicapai, dan keputusan itu makin mendekatkan pada suatu tujuan tersebut

MenurutProf.Dr.PrajudiAtmosudirjo,SH.menyatakanbahwa Keputusaniala $\mathrm{h}$ suatu pengakhiran dari proses pemikiran tentang suatu masalah atau problema untuk menjawab suatu pertanyaan apa yang harus diperbuat guna untuk mengatasi masalah tersebut, dengan menjatuhkan sebuah pilihan pada suatu alternatif.

Didalam mengambil suatu keputusan harus ada pertimbanganpertimbangan dalam mengambil keputusan agar tidak salah dalam mengambil suatu keputusan.

\section{PENDIDIKAN}

pengertian pendidikan adalah proses mengembangkan kemampuan diri sendiri dan kekuatan individu. Sedangkan menurut Kamus Bahasa Indonesia, pendidikan adalah proses pengubahan sikap dan tata laku seseorang atau kelompok orang dalam usaha mendewasakan manusia melalui upaya pengajaran dan pelatihan.

Pendidikan dapat diperoleh baik secara formal dan non formal. Pendidikan secara formal diperoleh dengan mengikuti program-program yang telah direncanakan, terstruktur oleh suatu insititusi, departemen atau kementtrian suatu negara. Sedangkan pendidikan non formal adalah pengetahuan yang diperoleh dari kehidupan sehari-hari dari berbagai pengalaman baik yang dialami atau dipelajari dari orang lain.

\section{PEKERJAAN}

Pekerjaan dalam arti luas adalah aktivitas utama yang dilakukan oleh manusia. Dalam arti sempit, istilah pekerjaan digunakan untuk suatu tugas atau kerja yang menghasilkan uang bagi seseorang. Dalam pembicaraan sehari-hari istilah ini sering dianggap sinonim dengan profesi.Jika pada pengertian perusahaan unsure laba merupakan unsure mutlak, maka pada pengertian pekerjaan unsure 
laba tidak merupakan unsure mutlak. Jadi dasar perbuatan-perbuatan yang dilakukan bagi suatu pekarjaan itu tidak untuk mencari laba, tetapi misalnya atas dasar cinta ilmiah, perikemanusiaan, atau agama.

Menurut pendapat Pemerintah Belanda Perncanaan Wetboek van Koophandel, pekerjaan itu perbuatan-perbuatan yang dilakukan tidak terputusputus, secara terang-terangan dan dalam kedudukan tertentu. Jadi, laba tidak merupakan unsure mutlak. Menurut Polak pekerjaan itu dapat direncanakan sebelumnya dan dicatat meskipun tidak dicatat dalam pembukuan), tetapi memperhitumgkan laba-rugi.

\section{METODE PELAKSANAAN}

Metode pelaksanaan pengabdian ini dilakukan dalam beberapa kegiatan yaitu tahap survei yaitu sosialisasi dilakukan dengan menyusun berbagai hal yang akan disampaikan pada saat kegiatan pengabdian yang akan dilakukan yang meliputi: penyusunan materi yang akan diberikan, penyusunan jadwal pemberian materi, pembagian tugas tim pengabdian dan survei ke lokasi pengabdian. Tahap sosialisasi yaitu sebelum kegiatan pengabdian dilaksanakan terlebih dahulu dilakukan tahap sosialisasi yaitu melakukan silaturahmi dengan ketua yayasan, menyampaikan maksud dan tujuan pengabdian ini. Pada tahap ini juga dilakukan jalinan kerjasama dan menentukan jadwal kegiatan pengabdian. Tim pelaksana kegiatan pengabdian pada masyarakat adalah dosen Fakultas Ekonomi jurusan manajemen sebanyak 11 orang. Tim pengabdian memberikan materi tentang enterpreneur dan jiwa leadership di SMK LETRIS INDONESIA II J1.Siliwangi No.47 Pamulang. Tangerang Selatan dan akan memberikan pelatihan disana.

\section{PRA KEGIATAN}

Persetujuan proposal pengabdian masyarakat pada kampus Universitas Pamulang dan SMK LETRIS II Jl.Siliwangi No.47 Pamulang. Tangerang Selatan guna membekali Para dengan ilmu bagaimana menentukan pilihan setelah lulus sekolah nanti

Kegiatan ini meliputi bagaimana menjadi leadership dan enterprener muda, Para siswa dan siswi menjadi terbuka dan mampu mengatur kehidupan financial mereka secara mandri dan bermanfaat untuk orang lain. Tampa melepas masa kanak-kanak mereka, segala keterampilan yang merka terima tetap dapat terlaksana.

Persiapan yang dilakukan adalah segala hal yang terkait dengan materi, bahan dan alat sesuai dengan tema secara baik. Hasil persiapan tersebut dimaksudkan agar materi tersampaikan dengan dan mudah dimengerti serta 
dipahami oleh para siswa siswi SMK LETRIS II Jl.Siliwangi No.47 Pamulang. Tangerang Selatan.

\section{HASIL DAN PEMBAHASAN}

Pengabdian Masyarakat (LPPM) Universitas Pamulang yang dilakukan oleh dosen-dosen program studi Manajemen telah berjalan dengan lancar dan mendapat sambutan hangat dari tempat pelaksanaan kegiatan ini yaitu SMK (Sekolah Menengah Kejurusan ) Letris Indonesia II Pamulang, Tangerang Selatan

Harapan kami dengan pengabdian ini dapat membuka wawasan dari siswa siswi kelas 12 yang akan menghadapi dunia perguruan tinggi dan dunia kerja. Materi yang kami berikan yaitu pembelajaran dan praktek dalam bidang manajemen khususnya manajemen sumberdaya manusia yang baik sekaligus bahan kajian dan masukan bagi para siswa/siswi tersebut untuk dapat mengimplementasikannya dalam kehidupan sehari-hari agar bias menentukan masa depan yang cermelang, sehingga dapat membantu dan meningkatkan tingkat keilmuan dan keperibadian yang sehat dan bebas dari narkoba yang akan sangat bermanfaat dalam kehidupan mereka pada masa yang akan datang.

\section{KESIMPULAN DAN SARAN Kesimpulan}

Peserta kurang mengerti apa yang harus dilakukan setelah lulus sekolah SMA nanti haru kuliah atau harus berkerja dan bagaimana cara memilih mana yang harus diproritaskan . Peserta juga belum mengetahui bagaimana memilih peluang dan apa yang harus dipilih nanti setelah lulus sekolah.

\section{Saran}

Setelah pengabdian ini diharapkan peserta dapat membangun enterpreneur dan memiliki jiwa leadership serta mengajak teman/peserta lainnya untuk ikut menjadi enterpreneur dan memilih kampus mana yang nanti mereka tuju. Tim pengabdian agar terus melakukan kegiatan-kegiatan serupa secara berkesinambungan di masa yang akan datang

Selain itu diharapkan dengan pengabdian kepada masyarakat tersebut keberadaan perguruan tinggi dapat memberikan kontribusi besar kepada pengembangan dan penerapan keilmuan kepada masyarakat. Metode yang digunakan pada Pengabdian Kepada Masyarakat ini berupa ekspositori yaitu penyampaian materi secara verbal dan inquiry yaitu pembelajaran yang menekankan pada proses berpikir kritis dan analitis terkait kelimuan manajemen sumber daya manusia dan manajemen pemasaran dengan pemahaman mendalam terkait materi bagaimana menentukan masa depan . 
Hasil pengabdian masyarakat yang diperoleh adalah bertambahnya keilmuan bagi para Para Siswa dan Siswi SMK LETRIS INDONESIA II J1.Siliwangi No.47 Pamulang. Tangerang Selatan", agar mereka memiliki pandangan yang baik bagaimana cara menentukan pilihan setelah lulus sekolah, lanjut pendidikan atau bekerja, memiliki bekal pengetahuan tentang dunia usaha dan dunia akademisi setelah mereka lulus sekolah serta mampu mencetak generasi muda yang handal serta berprestasi dan dapat menjadi contoh bagi para remaja lainnya.

Ilmu yang diperoleh pada Pengabdian Masyarakat kali ini diharapkan mampu memberikan semangat baru bagi kita dalam menyampaikan materi dan motivasi serta berkontribusi bagi generasi muda, baik dilingkungan sekolah, kampus dan keluarga.

\section{DAFTAR PUSTAKA}

Arikunto, Suharsimi. 2008. Dasar-Dasar Evaluasi Pembelajaran. Jakarta: Bumi Aksara. 308 hlmn.

A.M. Sardiman, 2001. Interaksi dan Motivasi Belajar Mengajar. Jakarta: Raja GrafindoPersada. 224 hlmn.

Kartini Kartono, 2008, Pemimpin dan kepemimpinan. Jakarta: Raja Grafindo Persada

Prijosaksono, Aribowo dan Sri Bawono.2005. The Power of Entrepreneurial Intelligence,Membangun Sikap dan Perilaku Entrepreneur Dalam Diri Anda. Elex Media Komputindo, Jakarta

Edhi Prasetyo M. Wahyuddin. 2011. Jurnal . 'Pengaruh Kepuasan Dan Motivasi Kerja Terhadap Produktivitas Kerja Karyawan Riyadi Palace Hotel Di Surakarta'’. Program Pascasarjana Universitas Muhammadiyah Surakarta Jalan A. Yani, Tromol Pos 1, Pabelan, Surakarta 57102

Handoko,T.Hani. 2012. Manajemen Personalia dan Sumber Daya Manusia. Edisi Ke-2. Yogyakarta: BPFE.

L.Mathis., Robert dan John H.Jackson.Manajemen Sumber Daya Manusia. PT.Salemba 4. Jakarta. Edisi 10. 2006

Malayu Hasibuan S. P. 2012. Manajemen Sumber Daya Manusia. Cetekan keenam belas. Jakarta. PT. Bumi Akasara.

Mangkunegara, A.A Anwar Prabu. 2009. Manajemen Sumber Daya Manusia. Bandung: PT. Remaja Rosdakarya.

Mangkunegara.,Anwar Prabu. Manajemen Sumber Daya Manusia Perusahaan. PT.Remaja Rosdakarya. Bandung. Cetakan ke-12. 2013 
Marosno. 2013. Pengaruh Motivasi dan Disiplin Kerja Terhadap Kinerja Karyawan pada PT Satwiga Musiga Naga Contract. Skripsi. Tangerang Selatan.

Marwansyah. Manajemen Sumber Daya Manusia. CV Alfabeta. Bandung. 2010

Ma`ruf., Abdullah. Manajemen Dan Evaluasi Kinerja Karyawan. Swanda Presindo. Yogyakarta. 2014

Nawawi., Hadari. Perencanaan SDM (Untuk Organisasi Profit Yang Kompetitif). Gadjah Mada University Press. Cetakan ke-5. 2010

\section{DOKUMENTANSI FOTO KEGIATAN}
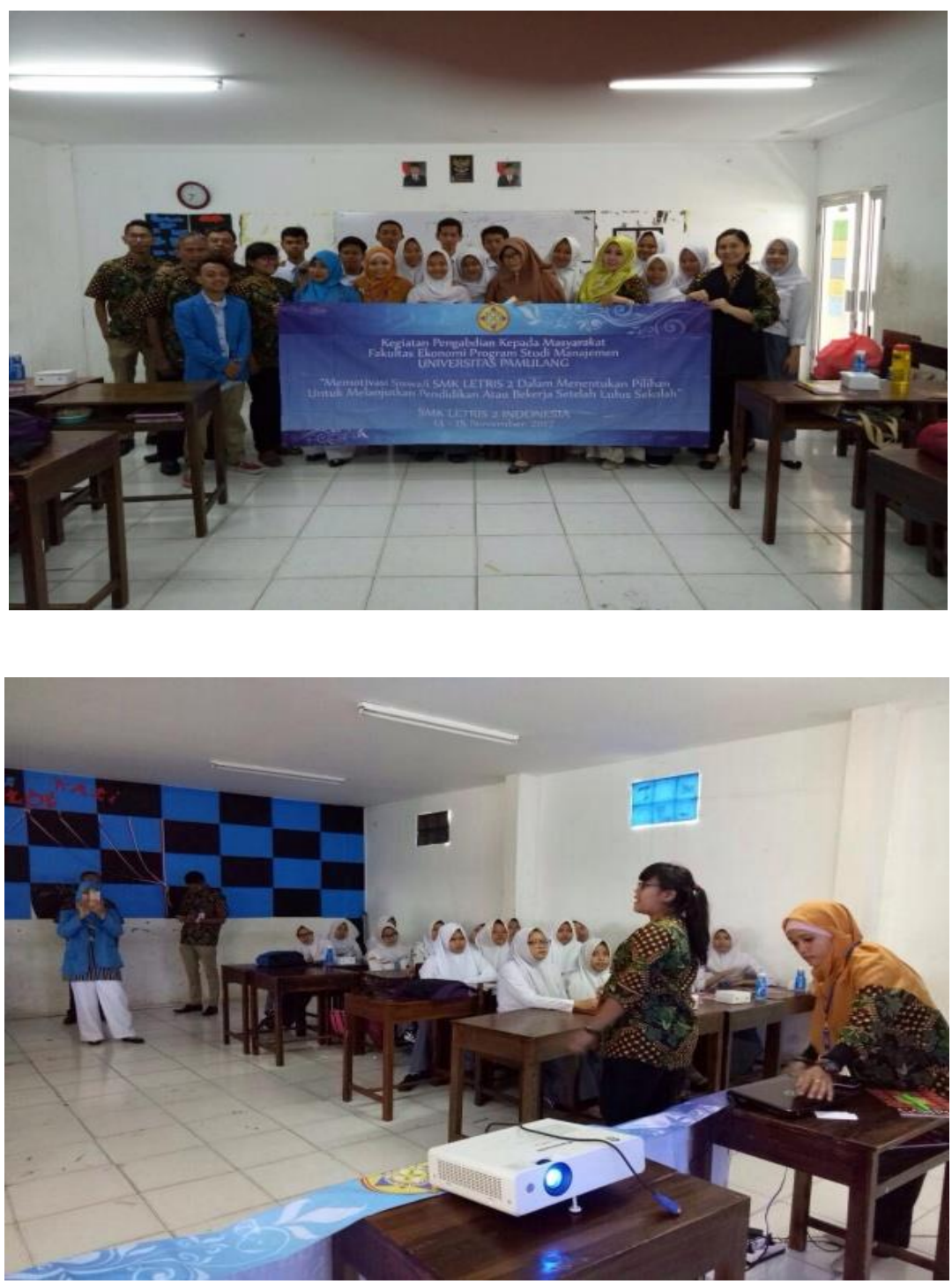